\title{
NATIONAL POLICY FOR REGIONAL DEVELOPMENT IN SOUTHWESTERN PARANÁ
}

https://doi.org/10.4215/rm2020.e19025

Lucas Henrique Campos Vasconcelos ${ }^{{ }^{*}}$ - Ideni Terezinha Antonello b

(a) Msc. in Geography. Londrina State University, Londrina (Pr), Brazil

ORCID: http://orcid.org/0000-0001-8143-3489. LATTES: http://lattes.cnpq.br/9219448667843209.

(b) Phd. in Geography. Paulista State University Júlio de Mesquita Filho, Rio Claro (SP), Brazil

ORCID: http://orcid.org/0000-0002-6147-4731. LATTES: http://lattes.cnpq.br/4011164128230924.

Article history:

Received 08 July, 2020

Accepted 09 September, 2020

Publisher 15 October, 2020
(*) CORRESPONDING AUTHOR

Address: UEL. Rodovia Celso Garcia Cid, Pr 445 Km 380, Cx. Postal 10.011, CEP 86.057-970, Londrina ( PR), Phone (+55 43) 3371-4000.

E-mail: lucasig1000@hotmail.com

\begin{abstract}
The research that gave rise to this article was aimed at analyzing the implementation of the National Policy for Regional Development programs in the Southwestern region of Paraná. On February 22, 2007, through Decree No. 6,047, the National Policy for Regional Development (PNDR, in Portuguese acronym) was institutionalized and on May 30, 2019, through Decree No. 9,810, the II National Policy for Regional Development came into force. In this article, the Program for the Promotion of Sustainability of Sub-Regional Spaces (PROMESO) and the Program for the Promotion of Development of the Border Strip (PDFF) will be analyzed, both with actions developed by the PNDR in the Southwestern Paraná Mesoregion. The article adopts an analytical nature, based on a theoretical-conceptual survey, documental analysis and case study, from a qualitative perspective. The results show that the PNDR had important actions in the southwestern region of Paraná, although it did not achieve the expected results due to the non-application of the proposed planning.
\end{abstract}

Keywords: Regional Development. Territorial Planning. Public Policy.

\section{Resumo / Résumé}

\section{POLÍTICA NACIONAL DE DESENVOLVIMENTO REGIONAL NO SUDOESTE DO PARANÁ}

A pesquisa que deu origem a este artigo teve como intuito a análise da implementação dos programas de atuação da Política Nacional de Desenvolvimento Regional na mesorregião Sudoeste do Paraná. Em 22 de fevereiro de 2007, por meio do Decreto $\mathrm{n}^{\circ} 6.047$, foi institucionalizada a Política Nacional de Desenvolvimento Regional (PNDR) e, em 30 de maio de 2019, mediante o Decreto n ${ }^{\circ}$ 9.810, entrou em vigência a II Política Nacional de Desenvolvimento Regional. Neste artigo, serão analisados o Programa de Promoção da Sustentabilidade de Espaços Sub-Regionais (PROMESO) e o Programa de Promoção de Desenvolvimento da Faixa de Fronteira (PDFF), ambos com ações desenvolvidas pela PNDR na mesorregião Sudoeste do Paraná. O artigo possui caráter analítico, efetuado com base em levantamento teórico-conceitual, análise documental e estudo de caso, por uma perspectiva qualitativa. Os resultados sinalizam que a PNDR teve ações importantes na mesorregião Sudoeste do Paraná, embora não tenha atingido os resultados esperados em razão da não aplicação do planejamento proposto.

Palavras-chave: Desenvolvimento Regional. Planejamento Territorial. Política Pública.

\section{POLITIQUE NATIONALE DE DÉVELOPPEMENT RÉGIONAL DANS LE SUD-OUEST DE PARANÁ}

La recherche qui a donné lieu à cet article avait pour objectif d'analyser la mise en œuvre des programmes d'action de la Politique Nationale de Développement Régional dans la région du Sud-Ouest du Paraná. Le 22 février 2007, par le décret n 6047 , la Politique Nationale de Développement Régional (PNDR, dans l'acronyme en Portugais) a été institutionnalisée. Le 30 mai 2019 , par le décret n ${ }^{\circ} 9810$, la II Politique Nationale de Développement Régional est entrée en vigueur. Dans cet article, le Programme pour la Promotion de la Durabilité des Espaces Sous-Régionaux (PROMESO) et le Programme pour la Promotion du Développement de la Bande Frontalière (PDFF) seront analysés, tous deux avec des actions développées par le PNDR dans la région Sud-Ouest du Paraná. L'article a un caractère analytique, réalisé à partir d'une enquête théorico-conceptuelle, d'une analyse documentaire et d'une étude de cas, d'un point de vue qualitatif. Les résultats montrent que le PNDR a mené des actions importantes dans la région du Sud-Ouest du Paraná, bien qu'il n'ait pas atteint les résultats escomptés en raison de la non-application de la planification.

Mots-clés: Développement Régional. Aménagement Du Territoire. Politique Publique. 


\section{INTRODUCTION}

The discussions related to the theme "Regional Development" have become widely disseminated in the academic environment and in public policies, aiming at strategies to equalize the development in the territory. Despite theoretical and methodological advances, there is still no consensus in the literature on the causes that justify spatial and economic asymmetries.

However, although there are no consistent bases to explain the success or failure of the regions, the permanence or deepening of regional inequalities must be faced, especially from the perspective of the State, which has the duty to manage the territory in its entirety. And, in this sense, public policies are indispensable to face the worsening of territorial inequalities.

The institutionalization of the National Policy for Regional Development (PNDR, in Portuguese acronym 1 ) was aimed at mitigating or correcting regional inequalities, not strictly fighting poverty. To this end, actions were prioritized on two basic pillars in the selected territories: the social organization of regional actors and the generation of employment and income, based on the development of local productive arrangements (APL). In this context, this article is the result of a Master's in Geography research that is based on the hypothesis that several initiatives were put into practice in the PNDR with the purpose of providing a better spatialization of development, but not always efficient due to the distortion of the proposed planning, as recurrent in the public management of the country.

The objective of this research is to analyze the National Policy of Regional Development in the Southwest Paraná (Figure 1). The Program for the Promotion of Sustainability of Sub-Regional Spaces (PROMESO) and the Program for the Promotion of Development of the Border Strip (PDFF) were analyzed, because it is through them that the management strategies of the PNDR occurred in the Southwest Paraná mesoregion.

In addition, an attempt was made to incorporate the recent debate on updating the proposed Policy in Decree No. 9,810 of May 2019, especially with regard to the state of Paraná. This investigation has an evaluative character, carried out by means of a theoretical-conceptual survey, documental analysis and data and case studies, from a qualitative perspective.

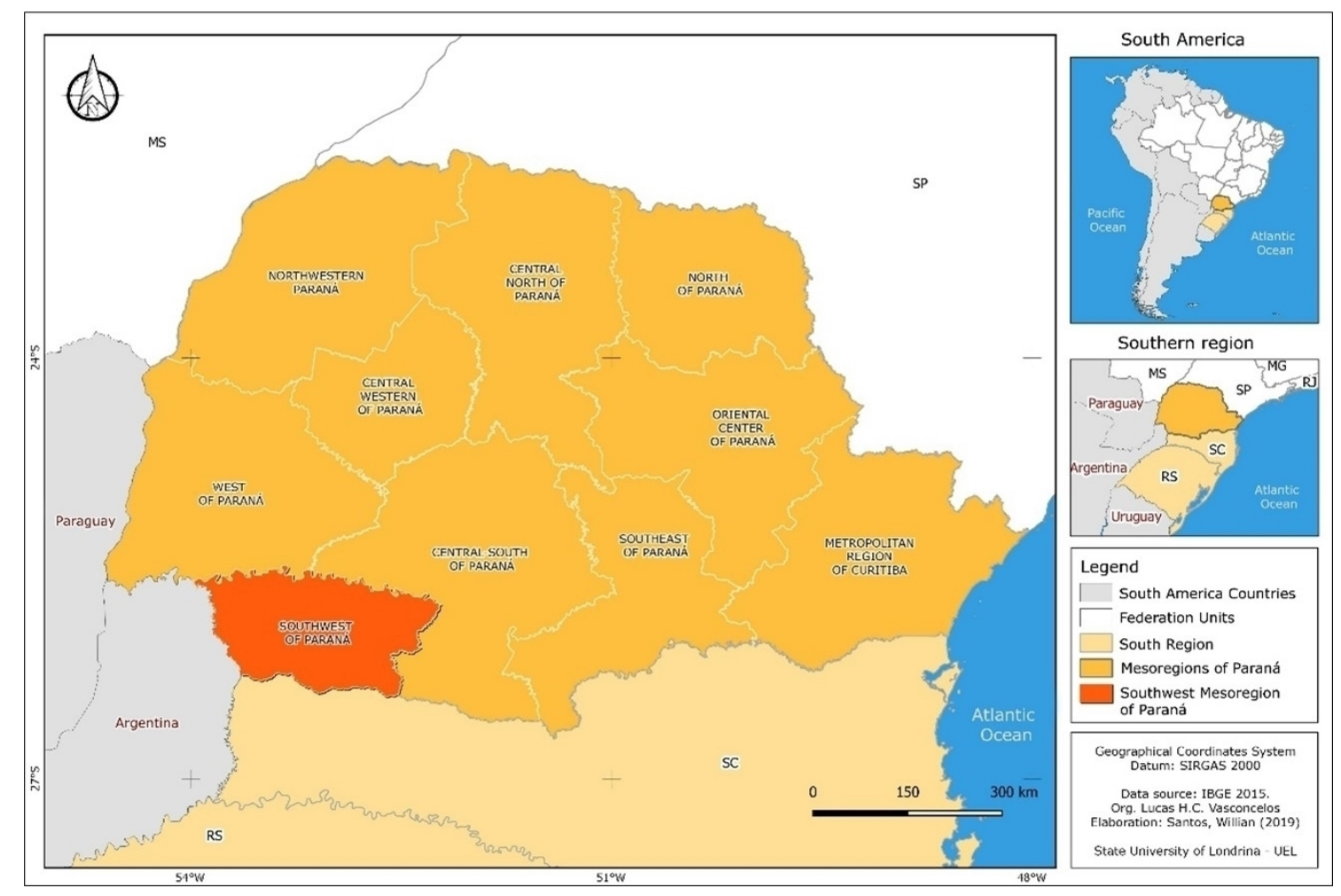

Figure 1 - Location of the Southwestern region of Paraná. Source: IBGE (2018)

The Southwest Paraná Mesoregion, a spatial cutout of this research, is located on the Third 
Plateau of Paraná and covers an area of 1,163,842.64 hectares, which corresponds to about $6 \%$ of the state territory. This region borders Argentina to the west, from the mouth of the Iguaçu River, and the south with the state of Santa Catarina, to the east and northeast borders the center-south region of Paraná and northwest borders the west region of Paraná. It is composed of 42 cities (IPARDES, 2020).

This article is divided into three main structures: "National Policy of Regional Development", "Execution of PROMESO in the Southeast Paraná Master Region" and "Implementation of PDFF in the Southeast Paraná Master Region". The first one focuses on the National Policy of Regional Development, discussing its typology, programs, sources of funding and mechanisms of intervention. The second and third are based on the analysis of the operationalization of PROMESO and PDFF in Southwest Paraná, highlighting its objectives, implementation period and assisted spaces. At last, the final considerations.

\section{NATIONAL POLICY FOR REGIONAL DEVELOPMENT}

In Brazil, between the late 1970s and early 1990s, territorial planning and regional development were relegated to a second plan. During this period, the process of redemocratization, the monetary crisis, foreign debt and inflationary problems monopolized the attention of the public agenda (VAINER, 2007). At the same time, the Keynesian-Fordist state model that had been in place since the beginning of the century began to show signs of exhaustion, allowing the rise of the regime of flexible accumulation (HARVEY, 1992).

As a consequence, the Brazilian State assumed functions more aligned to controlling and regulation than to promote economic activities and social welfare. Only in the late 1990s, and more intensely in the 2000s, with the stabilization of the economy and in the face of deep regional inequalities, did territorial planning and regional development return to central discussions of public policy.

The proposal, in 2003, and the institutionalization, in 2007, through the Decree of Law No. 6,047, of the National Policy for Regional Development, occurred with the purpose of mitigating or correcting regional inequalities, not only fighting poverty. The definition of priority territories for the I PNDR's action was a combination of two basic indicators published by IBGE in 1991 and 2000: i) per capita income, at the microregional level, and ii) the geometric rate of variation of municipal gross domestic products, at the microregional level, with the exception of the northern states, because some municipalities have large territorial dimensions. Thus, a division was established into four microregional categories that typify the Brazilian regional situation, called: 1) high income; 2) dynamic; 3) stagnant and 4) low income, as Figure 2 shows. 


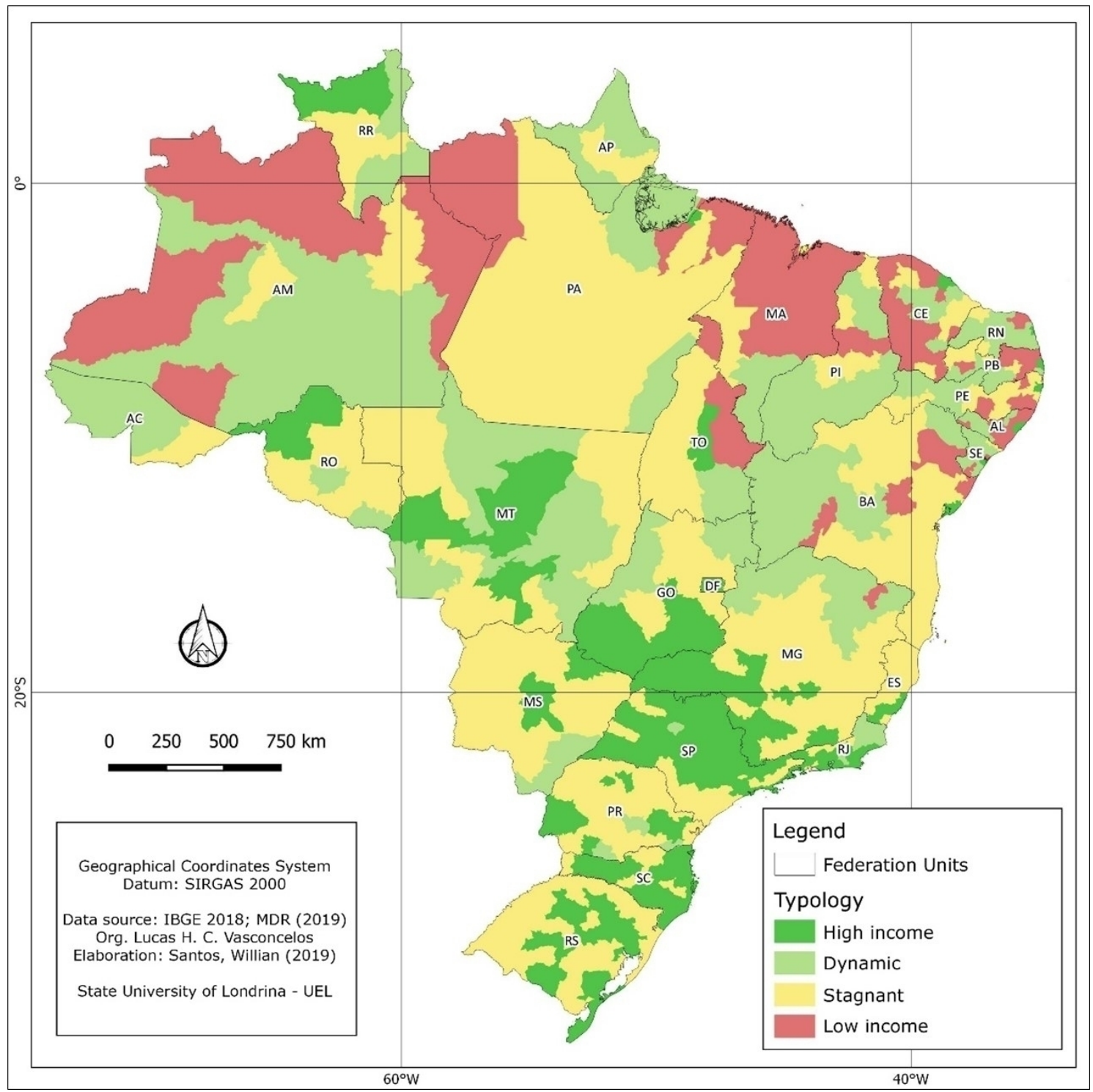

Figure 2 - Brazil - Typology of the National Policy for Regional Development (2019). Source: Ministry of Regional Development (2019)

In the I PNDR, micro-regions understood as dynamic, stagnant and low-income were defined as priorities. Starting in 2012, all the micro-regions in the Midwest, North and Northeast regions became priorities. It was found that the definition of the typology based on only two indicators hindered the understanding of the diverse and complex Brazilian territorial configuration. In 2012, at the I National Conference on Regional Development (I CNDR), the need to create a typology embodied in new variables that would allow a deepening of knowledge about the Brazilian regional dynamics was signaled, in order to contribute to the development of strategies compatible with the peculiarities of each space. By April 2020, the typology had not been reformulated. The Decree No. 9,810, which instituted the II PNDR, provides that the typology established by the Ministry of Regional Development will remain in effect until the first revision of the typology, which will occur after the publication of the 2020 Demographic Census. The Decree states that the new typology will have as a territorial cutout the immediate geographic regions established by IBGE, despite the lack of precision on the criteria used to define the immediate geographic regions that will be prioritized by the Policy.

In relation to the program financing, the PNDR has as a base of resources the General Budget of the Union (OGU) and of the federated entities, the Constitutional Financing Funds (of the Midwest, North and Northeast), the Regional Development Funds and fiscal subsidies. In the initial proposal of the PNDR, the creation of the National Fund for Regional Development (FNDR) was foreseen. In 2015, 
the FNDR was approved by the Federal Senate Committee on Economic Affairs (CAE), but until 2019, the proposal was still being processed by the Committee on Constitution, Justice and Citizenship (CCJ). The territories located outside the Northern, Northeastern and Central macro-regions do not benefit from the resources of the Constitutional Financing Funds, nor from fiscal subsidies, being restricted to the general budget of the Union via parliamentary amendments and complementary projects.

At the I CNDR (2012), it was found that the non-consolidation of the National Regional Development Fund decisively compromised the execution of the PNDR. Due to the low budget, the Policy's programs were inflated by parliamentary amendments that had little to do with reducing regional inequalities.

Although they are legitimate and legal instruments in the Brazilian political system, and count as one of the strategies of the PNDR, parliamentary amendments can interfere negatively in the results of public policies, for several reasons. In the case of the PNDR, this was done outside of the proposed planning, distorting the conception of projects. In addition, there is an imminent risk that these resources will be used to serve the personal interests of parliamentarians and their bases (ROCHA NETO, 2012).

In 2009, an audit was carried out with the objective of identifying risk events in the National Regional Development Policy, and to guide the selection of areas or themes that may be subject to control actions by the TCU. The survey sought to: i) analyze the formulation and implementation mechanisms of the PNDR; ii) evaluate the forms of control and coordination of government action; iii) learn about the sources of financing for the policy, including operations conducted by the funds and fiscal incentives granted; iv) learn about programs classified as policy instruments and v) learn about the status of funds used for financing (TCU/ACÓRDÃO 2,919/2009).

Several problems were found: i) lack of indicators, targets and evaluation of results associated with the Policy and its programs; ii) lack of inter-ministerial coordination; iii) territorial distribution of resources not in conformity with the diagnosis of regional inequality outlined in the PNDR; iv) partial application of available resources; v) lack of monitoring of actions and their results, and vi) signs of insufficient internal controls of the entities that operate the policy instruments (TCU/ACÓRDÃO $2,919 / 2009)$.

In 2012, PROMESO and PDFF were suspended. Although there is no official explanation of the causes responsible for the discontinuation of these programs, it can be inferred that the various problems of management and implementation, as stated in Judgment 2.919/2009, contributed negatively to the suspension of the programs, since both presented several weaknesses in their process of operationalization. Therefore, not all projects developed by the PNDR will be presented in the Southwest Paraná mesoregion.

In the Southwest Paraná Mesoregion, the I PNDR worked through the Program for the Promotion of Sustainability of Sub-Regional Spaces (PROMESO), using the cutout of the Mesoregion Grand Frontier of Mercosur, and the Program for the Promotion of Development of the Frontier Strip (PDFF). In the next chapters, some actions of PROMESO and PDFF will be discussed in the Southwest Paraná Mesoregion. It is reinforced that the two programs were interrupted in 2012 and extinguished in 2019 by the II PNDR. However, the border strip continues to be a priority for the Policy, although there is no specific program for this area.

\section{EXECUTION OF THE PROMESO IN THE SOUTHWESTERN REGION OF PARANÁ}

The First National Policy for Regional Development brings as its strategy of action the intervention at various territorial scales, and shows that its main purpose at the sub-regional level is concentrated in the Differentiated Mesoregions (Figure 3), proposed in the Program to Promote the Sustainability of Sub-Regional Spaces (PROMESO). 


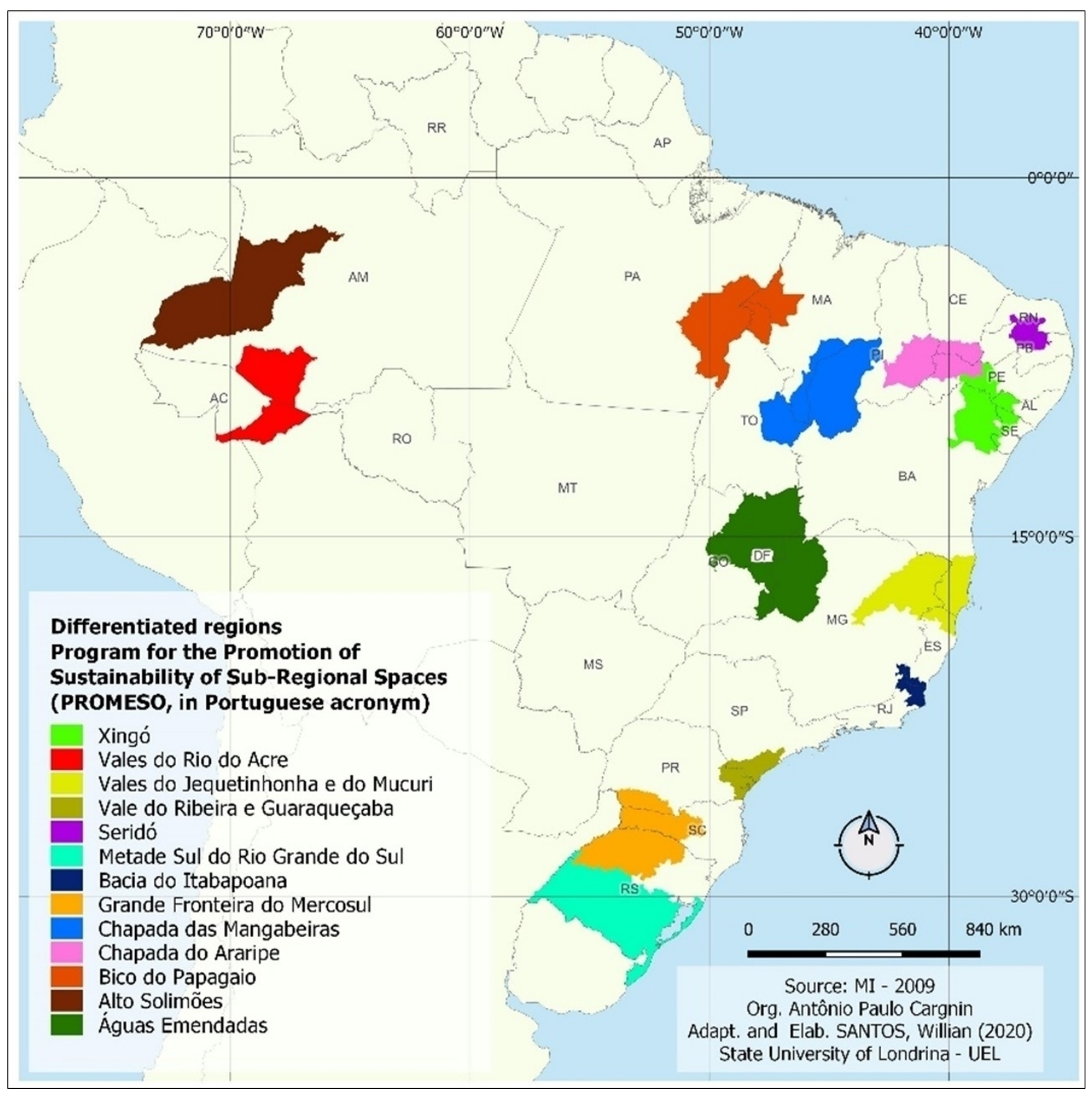

Figure 3 - Differentiated Mesorregions. Source: Adapted CARGNIN (2014, p. 60)

The Differentiated Mesoregions are contiguous subnational spaces, formed by one or more Units of the Federation, and may or may not obey the state limits (BRASIL/PROMESO, 2009), which makes them distinct from the Mesoregions adopted by the Brazilian Institute of Geography and Statistics (IBGE). Although they may cover territories in more than one state, the differentiated Mesoregions are smaller than the Macroregions.

The creation of the Differentiated Mesorregions was thought to have as its scope the possibility of forming a political-institutional arrangement with the participation of local society, mediated by the coordination and effectiveness of public policy actions of different spheres of power - municipalities, states and the Union. The Differentiated Mesorregions are formed by territories that present physical, economic, social, and cultural similarities (BRASIL/PROMESO, 2009).

In the Southwest Paraná Mesoregion, the Program for the Promotion of Sustainability of Sub-Regional Spaces acted using the cutout of the Mesoregion Grand Frontier of Mercosur, which covers part of the three states located in the Macroregion South of Brazil, comprising 381 municipalities, 208 in the northwest of Rio Grande do Sul, 131 in the west of Santa Catarina and 42 municipalities in the southwest of Paraná. It has a total area of approximately $121.000 \mathrm{~km}^{2}$ (BRASIL/PROMESO, 2009).

The creation of the Mesoregion Grand Border of Mercosur precedes the formulation of the PNDR, because in 1997 the mobilization of local actors from Rio Grande do Sul and Santa Catarina 
prepared the document called Sustainable Development Plan for the Uruguay River Basin Area. This region had in common the presence of municipalities with the highest rates of rural population that, in many cases, surpassed the urban one. These municipalities were highly dependent on rural and agro-industrial activities, which added to worrying socioeconomic indicators (CARGIN, 2014).

This initiative helped the Special Secretariat for Regional Policies (SEPRE) to prepare studies in 1998 containing criteria that triggered the programs for the Differentiated Regions. Thus, the Mesoregion of the Greater Mercosur Border became one of the 13 Mesoregions of Differentiation with actions inserted in the 2000-2003 Multiyear Plan. In the period that includes the 2004-2007 and 2008-2011 Multiyear Plans, the actions began to be organized by the Program to Promote the Sustainability of Sub-Regional Spaces, PROMESO.

According to PROMESO, there is a great disparity between the Mesoregion Grand Frontier of Mercosur and the rest of the Macroregion South. Although the Mesoregion comprises a quarter of the territory and a quarter of the population of the South, its gross domestic product corresponded to a little more than a tenth of the macro-regional GDP (BRASIL/PROMESO, 2009).

Among the difficulties affecting the Mesoregion, the following can be highlighted: i) relative impoverishment; ii) pressure of productive systems on natural resources; iii) increasing loss of dynamism of the regional economy in the face of the globalization phenomenon; iv) increase of individual poverty in face of difficulties of insertion of small property in the market; v) precarious housing conditions of a significant portion of the population and vi) absence of public services, such as sanitation, health and education (BRASIL/PROMESO, 2009).

In 2002, the Integrated and Sustainable Development Forum of the Mesoregion Grand Frontier of the Mercosur was created as a space for discussion, delineation and forwarding of local demands for a better allocation of public resources. They were responsible for implementing projects, municipal governments, foundations and non-governmental organizations, such as the Regional Development Agency of Southwest Paraná.

Between 2004 and 2011, the main projects developed in the Mesoregion Grand Frontier of Mercosur, with developments in the Mesoregion Southwest of Paraná (Figure 4), consist of the implementation and strengthening of family agroindustries, fish farming, viticulture, stoning and mineral crafts, furniture industry, transportation infrastructure and cultural projects.

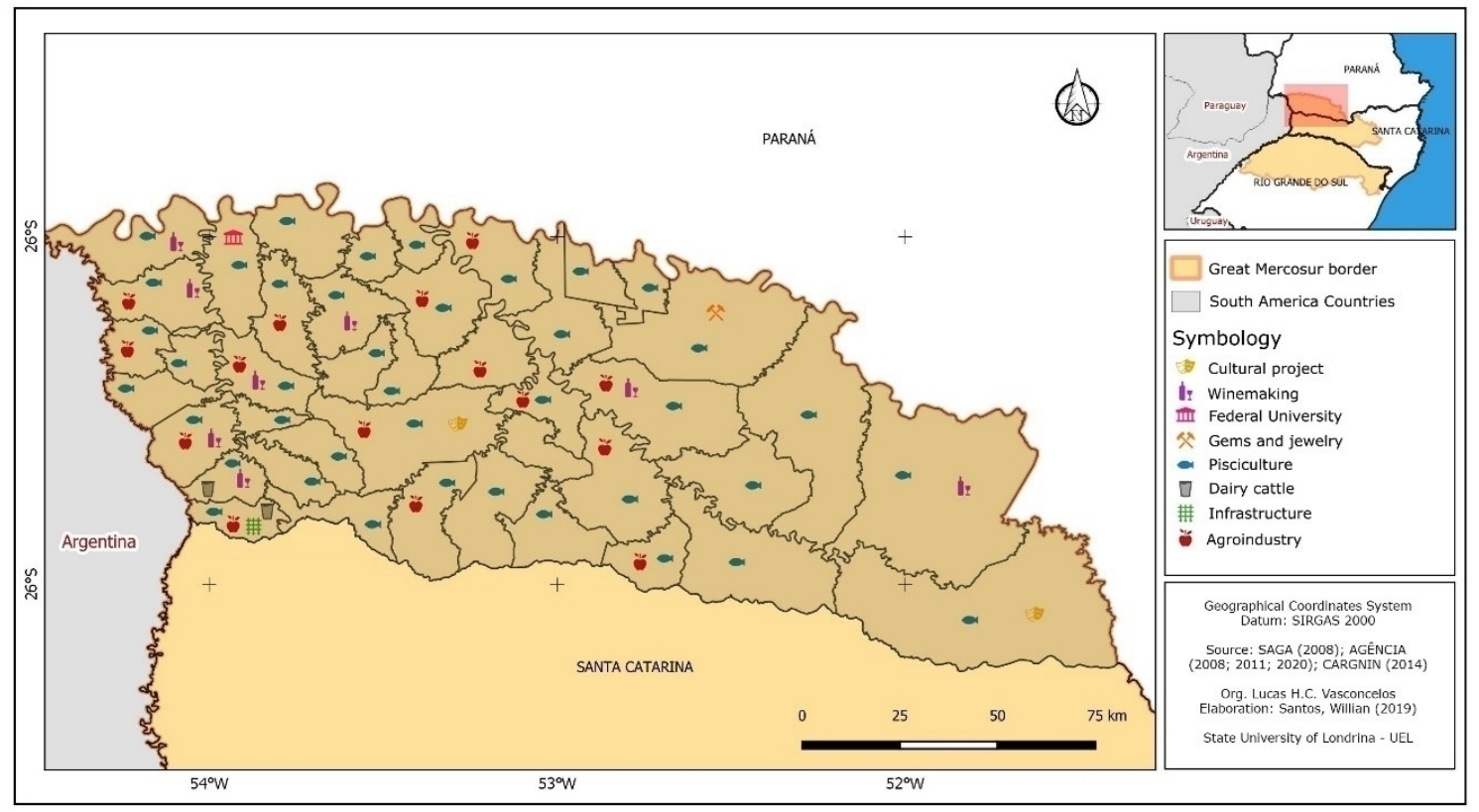

Figure 4 - PROMESO projects in the Southwest of Paraná, by municipality and follow-up, between 2003 and 2011. Source: SAGA (2008); AGÊNCIA (2008; 2011; 2020); CARGNIN (2014).

Two projects were developed to strengthen family agroindustries. The first, started in 2003 in the 
three southern states, supported the implementation and strengthening of companies through the acquisition of equipment and tools in the segments of milk, pork sausages, sweets and canned fruit and vegetables. In the first phase of the project, 51 agroindustries were supported, and in the second phase the goal was expanded to 150 agroindustries (CARGNIN, 2014, p. 64). The second started in 2005, and supported 76 agroindustries in the meat, milk, fruit and vegetable, yerba mate and sugar cane production chains. In Southwest Paraná, the municipalities assisted by the projects are well distributed by the mesoregion, due to the significant representation of the family agroindustry in the regional economy.

In 2007, the implementation of the project to strengthen fish farming in the area covered by the Mesoregion Grand Frontier of Mercosur was established. Due to the environmental conditions of the region (large quantity and quality of water and soil characteristics), the 42 municipalities of the Southwest Mesoregion were supported through training and purchase of equipment.

The project to strengthen viticulture began in 2005, serving seven municipalities in the southwestern region of Paraná. One hundred and fifty people were trained, and machines and equipment for grape processing were acquired. In 2009, there was another project to strengthen viticulture and cattle breeding in the municipalities of Barracão and Bom Jesus do Sul, which aimed to structure the enterprise (a wine canteen and a juice factory), and financial administrative management for a cheese factory and training in general. In 2011, another project was finalized to strengthen the wine growing activity in the region, but the data does not indicate the municipalities assisted.

With a view to the potential of Southwest Paraná in the production of gems and jewelry, especially amethyst, quartz, hyaline, agate and chalcedony, the project to support and structure the Center for the Formation of Hammers and Lapidators in the city of Chopinzinho (PR), in 2008, had as target audience 600 people to promote the production of hammered and cut gems, stone artifacts, handicrafts and jewelry design. In the first stage, training workshops were held with the support of the Municipality of Ametista do Sul (RS) and, in the sequence, processing and lapidating equipment were purchased, enabling the products to be processed in the region.

Regarding investments in infrastructure, in 2008 it was possible to recover $9.9 \mathrm{~km}$ of the BR-373 junction road, in the municipality of Barracão (PR). In the Mesoregion Grand Border of Mercosur, there were other investments in several areas, such as: education, health, culture, tourism, energy, technology, among others. In the case of the Southwest of Paraná, the support to culture in the cities of Palmas and Francisco Beltrão stands out.

Evidence of the creation of the Federal University of the Southern Frontier (UFFS), by Law No. 12,029 of September 15, 2009, with headquarters in Chapecó (Santa Catarina), with campuses in Realeza and Laranjeiras do Sul (Paraná), and Cerro Largo, Erechim and Passo Fundo (Rio Grande do Sul). That university (UFFS) was not included in the agenda of commitments of the Ministry of National Integration, nor in the Action Plan of the Mesoregion Grand Frontier of Mercosur, however, it had the support and demand of the Forum of the Mesoregion, which actively participated in the movement in favor of the implementation of the university (AGÊNCIA, 2020).

Although the PNDR typology was generated by two economic indicators, PROMESO's investments, with deployment in the Southwest of Paraná, insert institutional and social conditions as elements capable of generating opportunities for socioeconomic success in the assisted localities. In general, the actions are in line with the proposed planning. The fact that the projects were not restricted to the management of the then Ministry of National Integration contributes to this, since they were responsible for the execution of non-governmental organizations, municipalities and associations, following the example of the Regional Development Agency of the Southwest of Paraná.

On the other hand, it should be noted that the parliamentary amendments, despite being the main source of funding for PROMESO projects in the Southwest Mesoregion, were not located and, as a result, could not be evaluated by the research, although the analysis would contribute to a better understanding of the Program's implementation. Approximately $90.90 \%$ of the budget made by PROMESO was made up of parliamentary amendments. Several actions developed were not included in the planning, and were also unrelated to the objective of reducing regional inequalities (ACÓRDÃO 2.919/2009). The next chapter presents the execution of the PDFF in the Southwest Paraná. 


\section{IMPLANTATION OF PDFF IN THE SOUTHWEST PARANÁ MESOREGION}

The area of operation of the Program for the Promotion of the Development of the Border Strip comprises a vast strip of up to 150 kilometers wide along the 15,719 kilometers of the national land border, which encompasses 588 municipalities in 11 Federation Units: Acre, Amapá, Amazonas, Mato Grosso, Mato Grosso do Sul, Pará, Paraná, Rio Grande do Sul, Rondônia, Roraima and Santa Catarina. This area corresponds to $27 \%$ of the Brazilian territory and has approximately ten million inhabitants (BRASIL/PDFF, 2009).

The municipalities that border the neighboring countries are called the "border line". While they are classified as "twin cities", municipalities that have great potential for economic and cultural integration, and may or may not have a conurbation with a locality in the neighboring country, being articulated or not by an infrastructure work with the adjacent territory (BRASIL/DOU, 2014).

In the Southwestern region of Paraná, the Border Strip encompasses the 42 municipalities, 7 of which border the neighboring countries: Barracão, Bom Jesus do Sul, Santo Antônio do Sudoeste, Pranchita, Pérola d'Oeste, Planalto and Capanema. One municipality was classified as a twin city: Barracão (Figure 5).

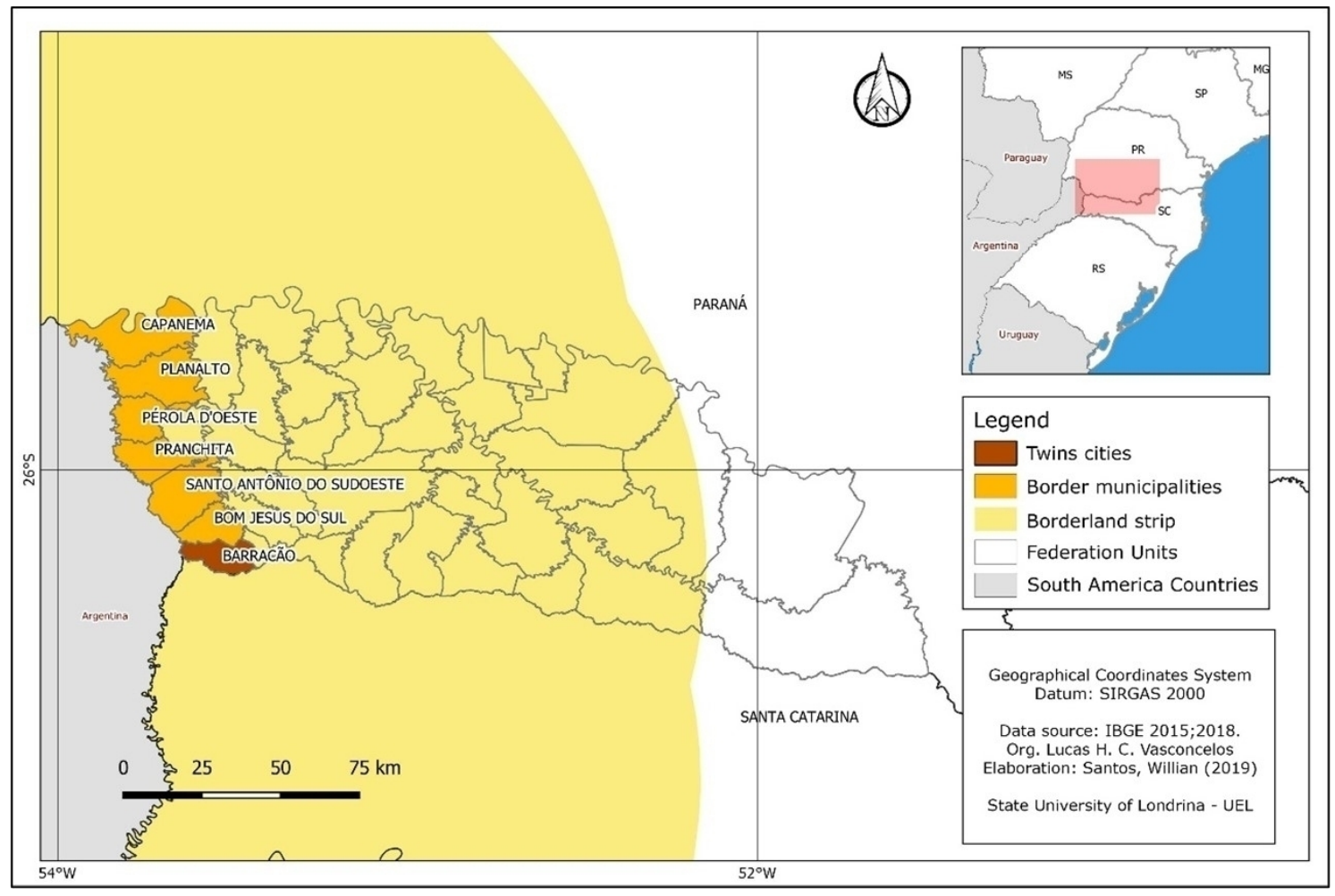

Figure 5 - Border Strip in Southwest Paraná. Source: IBGE (2015); IBGE (2018).

PDFF prioritizes the integrated development of twin-city regions, based on local potentialities, and of the differentiated Mesorregions that are located in the border strip. Among the 13 priority Mesoregions that are part of the Program for the Promotion of Sustainability in Sub-Regional Spaces (PROMESO), four of them are located in PDFF's area of coverage, among them the Mesoregion of the Greater Mercosur Border (PR, SC and RS). Therefore, the Southwest is a region doubly benefited by the PNDR.

In the Southwest of Paraná, the PDFF, in articulation with PROMESO, provided support to the development of local productive arrangements in the following segments: agroindustry, lumber $/ \mathrm{milk}$, textile sector, yerba mate, fruit farming, beverages and preserves, ceramic products, agricultural inputs (machinery), beef cattle farming, sheep farming, rice-growing, viticulture, tourism and beekeeping (BRASIL/PDFF, 2009). 
However, in practice, the initiatives committed by PROMESO and PDFF occurred in isolation. Few projects were supported by the Border Strip Development Program (PDFF) in the Southwest of Paraná until the end of its term in 2012. As in other PNDR programs, the territories located in the Southern Arc of Brazil do not benefit from the Constitutional Funds, and their execution is restricted to proposing parliamentary amendments, in most cases, without articulation with the established strategies.

It is worth mentioning a proposal of pilot experience in 5 twin cities in 2005: Tabatinga (AM) Letícia (Colombia); Ponta Porã (MS) - Pedro Juan Caballero (Paraguay); Dionísio Cerqueira (SC) Barracão (PR) - Bernardo de Irigoyen (Argentina); Uruguaiana (RS) - Paso de Los Libres (Argentina); and Santa do Livramento (RS) and Rivera (Uruguay). Table 1 shows the amounts authorized for the twin cities Barracão (PR) - Dionísio Cerqueira (SC) - Bernardo Irigoyen (Argentina), in the 2005 budget.

\begin{tabular}{|c|c|c|}
\hline FOLLOW-UP SUPPORTED & INITIATIVES & RESOURCES (R\$) \\
\hline Economic dynamization & 7 & $2.878 .148,67$ \\
\hline Economic infrastructure & 1 & $77.456,86$ \\
\hline Social infrastructure & 15 & $8.965 .113,30$ \\
\hline Social and institutional organization & 4 & $16.461,17$ \\
\hline Total & $\mathbf{2 7}$ & $\mathbf{1 1 . 9 3 7 . 1 8 0 , 0 2}$ \\
\hline
\end{tabular}

Table 1 - Table 1: Amounts authorized for the twin cities Barracão (PR) - Dionísio Cerqueira (SC) Bernardo Irigoyen (Argentina), in the 2005 budget

2. Source: MI Schedule of Commitments (2005)

It is noticeable that, in the 2005 planning, the initiatives are marked by a comprehensive performance. These interventions were expected to reduce inequalities and integration among assisted cities, as well as integrated regional development, in addition to improvements in the system of governance and participation of local society and the activation of local potentialities.

The investments authorized in the 2005 budget were not fully realized. According to Cargnin (2014), the few actions developed were basically restricted to infrastructure works. A project to strengthen viticulture in Southwest Paraná was carried out, but the data do not indicate the municipalities assisted, nor the amounts allocated.

According to the director of the Department of Regional and Urban Development of the Ministry of Regional Development, the PDFF was a program that did not come off "paper". It was basically a "drawer" program. Political and partisan interference emptied the program. In fact, in 2012, it was dismembered into two new programs: Regional Development, Sustainable Territory and Solidarity Economy and South American Integration?3.

According to the Director, because of political and party interference, the Program was distorted, and few actions were undertaken focusing on planning. PDFF had even less expressive results than PROMESO. In the case of PROMESO, there were the Forums, which although they presented weaknesses, brought historic advances when compared to centralized forms of government.

Several problems were found in the PDFF: i) lack of indicators, targets and evaluation of results; ii) lack of coordination; iii) irregular territorial distribution of resources; iv) partial application of available resources; v) lack of monitoring of actions and their results, and vi) insufficiency of internal controls of the government agencies that operated the Program (TCU/ACÓRDÃO 2,919/2009).

Paradoxically, the restructuring of the Border Strip Development Program in 2005 was negative from the execution point of view. In theoretical and normative terms, there were significant advances: i) the border strip began to be seen not only as an area of military strategy, and ii) regional inequalities began to be considered at their different territorial scales. However, with the reformulation of the program and the disclosure of the government, deputies and senators were discovering the program and 
using it for private interests via parliamentary amendments, which became increasingly present in the budget (CARVALHO, 2010, p. 219-222). In addition:

Among the main problems, it is worth mentioning the almost absence of treatment of transnational strategic issues in the scope of public policies. The most significant part of the actions considers only one side of integration, i.e., even if it has integration as its motivation, the Border Strip Development Program itself is more concerned with occasional economic restructuring of cities on the Brazilian side, without considering neighboring countries (CARGNIN, 2014, p. 73, own translation)4.

In 2010, the Permanent Commission for Integrated Border Strip Development (CDIF) was created to coordinate public policies in border regions. In 2011, the State Border Center of Paraná was created to outline and coordinate public policies at the federal, state and municipal levels in the border area. However, the state nuclei have shown themselves to be passive, without defined strategies, according to the Ministry of Regional Development. In 2019, the II National Policy for Regional Development maintained the border strip as a priority area, but does not indicate which program will be responsible for actions in this territorial portion.

It can be stated that the execution of the PNDR in the Southwest of the state of Paraná, through PROMESO and PDFF, did not achieve the expected results, because both programs presented several problems. As a consequence, they were extinguished. The operation of the PNDR in a disorderly manner is visibly expressed in the research and reports of the Court of Auditors of the Union, which shows the long distance between what was proposed and implemented, mainly due to lack of coordination, political interference and the non-approval of the National Fund for Regional Development.

\section{CONCLUSION}

The National Policy for Regional Development can be considered the framework for the resumption of territorial planning within the scope of public policies, especially for regions with low rates of economic dynamism and worrying socioeconomic indicators.

In the Southwest Paraná Mesoregion, the PNDR made possible the development of actions of both PROMESO, through the Mesoregion Great Border of Mercosur, and PDFF, from actions executed mainly in the city of Barracão. The projects carried out, and which could be located by this research, were consistent with the local reality, but most of the investments could not be located. The actions presented in the research were foreseen in the agenda of commitments of the Ministry of Regional Development (at the time, Ministry of National Integration), as in the Action Plan of the Mesoregion Grand Border of Mercosur.

Between PROMESO and PDFF, projects were developed for training, implementation / strengthening of local productive arrangements, creation of a federal university, organization of local / regional society and improvements in infrastructure.

Within PROMESO, it is worth highlighting the implementation of projects to strengthen agroindustries, fish farming and viticulture. Due to its capacity for transformation in the region, the Federal University of the Southern Frontier (UFFS) was created, with a campus in the cities of Realeza and Laranjeiras do Sul, in Paraná. Although it was not developed exclusively by Politics, the Forum of the Mesoregion Grand Frontier of Mercosur actively participated in the movement to reclaim the university.

PDFF, on the other hand, had a more subtle participation, being restricted to the implementation of a project to strengthen viticulture and infrastructure works, especially in Barracão, considered a priority due to its definition as one of the twin cities of the Program.

Considering that the PNDR was re-edited in 2019, the constitution of an institutional arrangement of cooperation between the instances of power and management is a great challenge for the efficiency of the actions to be developed. For this, the implementation of more democratic management mechanisms and the application of a system of vertical and horizontal cooperative governance are essential.

Finally, it is emphasized that the National Policy for Regional Development in the Southwestern region of Paraná has moved from the possibility of progress to the persistence of the problem, because 
the theoretical and normative progress proposed was not accompanied by an evolution of practical means of intervention. This made it impossible to apply the planned methodology, becoming a public policy devoid of content and effectiveness. This way of operating had a direct impact on the quality of government spending and on the efficiency of the results obtained by the Policy, besides signaling to society that the lack of coordination and inefficiency are characteristics of state interventions.

\section{NOTE}

1- All the acronyms of this text will be presented in Portuguese language

2- The monetary values used by the survey were updated to $04 / 2020$ by IGP-M FGV.

3- On December 18, 2019, an interview was conducted with the director of the Regional and Urban Development Department of the Ministry of Regional Development.

4- Original in Portuguese: Entre os principais problemas, pode ser destacada a quase ausência do tratamento de temas estratégicos transnacionais no âmbito das políticas públicas. A parcela mais significativa das ações considera apenas um lado da integração, ou seja, mesmo que apresente em sua motivação a integração, o próprio Programa de Desenvolvimento da Faixa de Fronteira tem como maior preocupação a reestruturação econômica pontual de cidades do lado brasileiro, sem considerar os países vizinhos (CARGNIN, 2014, p. 73).

\section{ACKNOWLEDGMENT}

To the Coordination for the Improvement of Higher Education Personnel (CAPES) for the scholarship.

\section{REFERENCES}

AGÊNCIA. Agência de Desenvolvimento Regional do Sudoeste do Paraná. 2020. Projetos executados. Available at: http://www.agenciasudoeste.org.br. Access on: 26 Feb. 2020.

AGÊNCIA. Agência de Desenvolvimento Regional do Sudoeste do Paraná. Relatório do Projeto de Fortalecimento do Arranjo Produtivo da Vitivinicultura na Mesorregião Grande Fronteira do Mercosul Porção Gaúcha, Catarinense e Paranaense. Agência de Desenvolvimento Regional do Sudoeste do Paraná: Francisco Beltrão, 2011.

AGÊNCIA. Agência de Desenvolvimento Regional do Sudoeste do Paraná. Relatório do Projeto de Implantação e Estruturação do Centro de Formação de Marteladores e Lapidadores do município de Chopinzinho (PR). Agência de Desenvolvimento Regional do Sudoeste do Paraná: Francisco Beltrão, 2008 .

BRASIL. Decreto de Lei $\mathrm{n}^{\circ}$ 6.047, de 22 de fevereiro de 2007. Institui a Política Nacional de Desenvolvimento Regional. Brasília, 2007. Available at: http://www.planalto.gov.br. Access on: 10 Sep. 2019.

BRASIL. Decreto de Lei $\mathrm{n}^{\circ}$ 9.810, de 30 de maio de 2019. Institui a Política Nacional de Desenvolvimento Regional e revoga o Decreto $\mathrm{n}^{\circ} 4.793$, de 23 de julho de 2003, e Decreto $\mathrm{n}^{\circ}$ 6.047, de 22 de fevereiro de 2007. Brasília, 2019. Available at: http://www.planalto.gov.br. Access on: 10 Jan. 2020.

BRASIL. Ministério da Integração Nacional. I Conferência Nacional de Desenvolvimento Regional: Documento referência. Brasília, Secretaria de Políticas Públicas de Desenvolvimento Regional, 2012.

BRASIL. Ministério da Integração Nacional. Programa de Promoção do Desenvolvimento da Faixa de Fronteira (PDFF). Brasília: Ministério da Integração Nacional, 2009.

BRASIL. Ministério da Integração Nacional. Programa de Promoção da Sustentabilidade de Espaços Sub-Regionais (PROMESO). Brasília: Ministério da Integração Nacional, 2009. 
BRASIL. Tribunal de Contas da União. Acórdão nº 2.919. Brasília, 2009.

CARGNIN, Antonio Paulo. Políticas de desenvolvimento regional no Rio Grande do Sul: vestígios, marcas e repercussões territoriais. $1^{\circ}$. Ed. - Brasília, DF: Ministério da Integração Nacional, 2014.

HARVEY, David. Condição Pós-Moderna. São Paulo: Loyola, 1992.

IBGE. Instituto Brasileiro de Geografia e Estatística.

Censo Demográfico - Censo 2020. 2020. Available at: https://www.ibge.gov.br/. Access on: 01 Aug. 2020 .

IBGE. Instituto Brasileiro de Geografia e Estatística.

Divisão Regional do Brasil em Regiões Geográficas Imediatas e Regiões Geográficas Intermediárias 2017. 2017. Available at: https://www.ibge.gov.br/. Access on: 01 Aug. 2020.

IPARDES. Instituto Paranaense de Desenvolvimento Econômico e Social. Perfil avançado das regiões. 2019. Available at: http://www.ipardes.pr.gov.br. Access on: 23 Dec. 2019.

ROCHA NETO, João Mendes da. Cooperação e competição entre políticas públicas no Brasil: os custos da governabilidade no presidencialismo de coalizão. Tese de Doutorado - Programa de Pós-Graduação em Administração, Universidade Federal do Rio Grande do Norte, Natal, 2012.

SAGA. Instituto de Desenvolvimento Regional. Relatório do Projeto de Fortalecimento e Implantação de Unidades Agroindustriais Mesorregião Grande Fronteira do Mercosul - Porção Gaúcha, Catarinense e Paranaense. SAGA. Chapecó: Instituto de Desenvolvimento Regional, 2008.

VAINER, Carlos Bernardo. Fragmentação e projeto nacional: desafios para o planejamento territorial. In: DINIZ, Clélio Campolina (Org.). Políticas de desenvolvimento regional: desafios e perspectivas à luz das experiências da União Européia e do Brasil. Brasília: Universidade de Brasília, 2007, p. 103-130. 